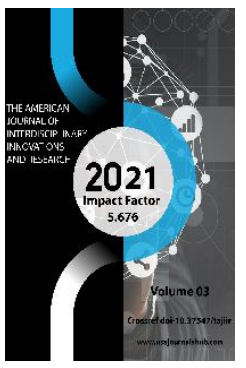

Journal Website: https://theamericanjou rnals.com/index.php/ta jiir

Copyright: Original content from this work may be used under the terms of the creative commons attributes 4.0 licence.

\section{Business Combination Process And Its Audit Review Of Financial Statements}

\author{
Komil Bahramovich Urazov \\ Ph.D., Professor, Samarkand Institute Of Economics And Service, Department Of Accounting \\ And Auditing, Uzbekistan
}

Jamshidbek Ahmad Ugli Abdurasulov

Master Of Accounting And Auditing, Samarkand Institute Of Economics And Service, Uzbekistan

\title{
ABSTRACT
}

Enterprises are known to be important subjects of accounting, which is the main link in the economy of any individual society, respectively, as a means of management. Through enterprises, tangible and intangible goods are created, various works are performed, services are provided and they are delivered to consumers. Increasing the number of enterprises, merging them, enlarging them, developing joint activities is one of the important factors in increasing the country's GDP, employment and income, improving living standards and welfare. This article reveals the basic rules of accounting and financial reporting in the context of reorganization of enterprises on the basis of existing laws and regulations, including national standards. The essence, features and procedures of reorganization of the main branches of the economy of the republic, respectively, the main subjects of accounting are revealed. The article also outlines the general requirements for accounting and financial reporting in the context of reorganization of enterprises.

\section{KEYWORDS}

Business, reorganization, addition, separation, recognition, valuation, accounting, financial reporting.

\section{INTRODUCTION}

By accelerating the transition of our economy to the International Financial Reporting Standards (IFRS), which have been used for many years in the practice of developed countries, providing foreign investors with the necessary information environment, increasing 
investment attractiveness and access to international financial markets, In order to improve the system of training of auditors in accordance with international standards, the Resolution of the President of the Republic of Uzbekistan Sh.M. Mirziyoyev dated February 24, 2020 No PD-4611 "On additional measures for the transition to international financial reporting standards" , plays a special role in determining the order of accounting for the reorganization of enterprises on the basis of foreign experience and their harmonization with international standards [1].

\section{RELEVANCE OF THE TOPIC}

Today in our country, business mergers, including mergers, acquisitions, divisions, separations, changes, are used to determine the order of disclosure in the financial statements of information on the processes carried out in accordance with IFRS 23. This IFRS applies to all businesses in the territory of the Republic of Uzbekistan [2].

In accordance with this national standard, the assessment of assets and liabilities transferred (accepted) in the reorganization of enterprises is carried out in accordance with the procedure established by the decision (agreement) of the founders on reorganization. For each type of assets and liabilities, a separate valuation method may be established that differs from the valuation methods used for other types of assets. However, a number of elements in the standard that require full coverage and ensure compliance with international standards are structurally different from IFRS 22, Consolidation of Enterprises.
The purpose of this standard is also to establish the procedure for reflecting the process of mergers of enterprises in an account such as IFRS. In IFRS 22, a merger of a company is classified as a merger or acquisition of shares. This standard covers the processes by which one entity acquires another and combines interests when the buyer is not identified. A business combination is not the purchase of shares in another company but the acquisition of the company's net assets with a business reputation [3].

The preparation of the financial statements in the context of the reorganization in accordance with IFRS 23 (paragraph 9) is based on:

a) Decisions of the founders or relevant bodies on reorganization;

b) Constituent documents of enterprises formed as a result of reorganization;

c) Agreements on merger, acquisition, division, separation and change of organizational and legal form in cases established by the legislation of the Republic of Uzbekistan;

d) Deed of transfer or balance sheet;

e) In accordance with the legislation of the Republic of Uzbekistan, the registration body: a record of newly formed enterprises in the form of merger, division, separation and change; a document confirming the inclusion in the Register of a record of the last cessation of the activities of the added enterprises in the reorganization in the form of annexation, etc. 
According to the decision (agreement) of the founders, the deed of transfer or distribution balance sheet includes the following applications:

a) Financial statements in the composition provided for in the Law of the Republic of Uzbekistan "On Accounting" [2], reflecting the structure of assets and liabilities of the reorganized enterprise, as well as their value from the date of registration of assets and liabilities to the last reporting date;

b) Assets and liabilities of the reorganized enterprise, carried out in accordance with IFRS 19 "Organization and conduct of inventory" [3] and confirming their correctness (availability, status and value of assets and liabilities) before drawing up the transfer deed or distribution balance sheet; inventory acts (registration documents);

c) Initial documents on tangible and intangible assets (fixed assets, intangible assets, inventories, etc.), lists of other assets to be received and transferred in the reorganization of enterprises (registration documents);

d) Information on reorganized enterprises notifying their creditors and debtors in writing of the transfer of property and obligations under relevant contracts and agreements, settlements with the relevant budgets, state trust funds, etc. from the date of state registration; decryption of the specified accounts payable and receivable (their registration documents), etc.

\section{RESEARCH RESULTS AND ANALYSIS}

Considering the process of merging a business, procurement differs in essence from the merging of interests, the content of which should be reflected in the financial statements. Accordingly, different methods of accounting are expressed for each of these species.

The standard sets out the criteria for determining the fair value of the identifiable assets and liabilities acquired. For example, securities are valued at current market value, at current prices at which receivables can be obtained, at the selling price of finished goods after deducting:

\section{(a) Exit costs;}

(b) The company's share of the expected profit from the buyer's actions to obtain the profit from the sale of the same finished product. It is intended to determine the fair value of the market value determined using the valuation of machinery and equipment. Accounts payable and promissory notes, long-term debts, liabilities and other accounts receivable are recorded at a discounted value based on current interest rates. Negative goodwill can also occur. Negative goodwill is written off the assets of the reporting company and recorded in the balance sheet in the same generally recognized classification.

In IFRS, assets transferred in the reorganization of enterprises can be valued at the following values:

a) At the actual cost of procurement; 
b) At cost;

c) At residual value;

d) At the cost of recovery;

e) At face value;

f) At the actual full cost of production;

g) At actual cost of production at direct costs;

h) At the planned, normative cost;

i) At market prices.

\section{CONCLUSION}

From the above, it can be concluded that ensuring the accounting of reorganization processes in accordance with international accounting standards, increasing investment attractiveness based on world-recognized evaluation criteria, easy and clear information to the user, ie processes such as mergers, acquisitions or conflicts of interest, synthesizes through the information provided and provides information on the financial condition of the enterprise. This, in turn, encourages the application of other aspects of IFRS to national accounting and auditing.

\section{REFERENCES}

1. Law of the Republic of Uzbekistan "On joint-stock companies and protection of shareholders' rights" (new edition), 26.04.1996 223-I-vol.

2. Law of the Republic of Uzbekistan "On Limited Liability and Additional Liability Companies", 06.12.2001 310-II-vol.
3. Law of the Republic of Uzbekistan "On Private Enterprise", 11.12.2003 No. 558II.

4. Law of the Republic of Uzbekistan "On Family Business", April 26, 2012 No. ORQ-327.

5. Law of the Republic of Uzbekistan "On business companies", 06.12.2001308-IIvol.

6. Regulations on state enterprises (approved by the Resolution of the Cabinet of Ministers of the Republic of Uzbekistan dated 16.10.2006 No. 215)

7. Uzdavstat website materials.

8. https://uz.sputniknews.ru/20210529/ch islo-gospredpriyatiy-v-uzbekistanesokratyat-na-75-k-2025-godu18977013.html.

9. Civil Code of the Republic of Uzbekistan, 21.12.1995.

10. IFRS 3 "Business Associations";

11. IFRS 10 "Consolidated Financial Statements";

12. IFRS 23 "Formation of financial statements in the course of reorganization".

13. IFRS 8 "Consolidated Financial Statements and Investments in Subsidiaries".

14. Plotnikov V.S., Plotnikova O, V. Business Combinations and Consolidated Financial Statements, Study Guide, -M .: Publisher: INFRA-M, 2018.

15. Tashnazarov S.N. Moliyaviy hisobotning nazariy va metodologik asoslarini takomillashtirish. Monografiya. - Publisher SIA OmniScriptum Publishing. GlobeEdit Publishing house. 2018. 280 p. ISBN13:978-613-8-24050-1, 87-107- betlar. 